\title{
PROFIL DAN KARAKTERISTIK LEMAK HEWANI (AYAM, SAPI DAN BABI) HASIL ANALISA FTIR DAN GCMS
}

\author{
S. Hermanto*, R. Harahap, E. Chevtia \\ Program Studi Kimia FST UIN Syarif Hidayatullah Jakarta \\ Email : hermantokimia@uinjkt.ac.id
}

\begin{abstract}
ABSTRAK
Telah dilakukan penelitian tentang analisa profil dan karakteristik beberapa lemak hewani sebagai studi pendahuluan dalam rangka pengembangan metode analisa kehalalan pangan. Sampling dilakukan terhadap tiga jenis sampel jaringan lemak hewani yang meliputi lemak ayam, lemak sapi dan lemak babi. Sampel jaringan lemak ayam dan sapi diperoleh dari pasar tradisional sedangkan sampel jaringan lemak babi diperoleh dari Rumah Pemotongan Hewan di daerah Jakarta Timur. Masing-masing sampel jaringan lemak diekstrak dengan pemanasan langsung dan selanjutnya dianalisa sifat fisikokimianya meliputi bobot jenis, indeks bias, titik leleh, bilangan asam, bilangan iod dan bilangan penyabunan. Analisa lebih lanjut dilakukan dengan metode FTIR (Fourier Transform Infra red) dan GCMS (Gas Chromatography Mass Spectromtery) untuk mengidentifikasi spesifitas masing-masing lemak berdasarkan pola serapan gugus fungsi dan komposisi asam lemaknya. Hasil analisa sifat fisikokimia yang diperoleh menunjukkan bahwa tidak terdapat perbedaan yang cukup signifikan untuk masing-masing sampel lemak kecuali untuk titik leleh, bilangan iod dan bilangan penyabunannya. Hasil analisa FTIR menunjukkan adanya perbedaan pola serapan yang khas pada daerah 3010, 1110-1095 dan 975-965 $\mathrm{cm}^{-1}$ yang merepresentasikan tingkat perbedaan komposisi asam lemak pada masing-masing sampel. Hal ini diperkuat dengan hasil analisa GCMS yang membuktikan adanya perbedaan kandungan SFA (saturated fatty acid), MUFA (monounsaturated fatty acid) dan PUFA (polyunsaturated fatty acid) pada ketiga sampel.
\end{abstract}

Kata Kunci : Lemak hewani, sifat fisikokimia, FTIR, GCMS, SFA, MUFA dan PUFA

\begin{abstract}
A research had been done to carried out the profile and characteristic of animal fat as a preface of developing food halalness analysis. Three different type of animal bady fat had been choose on the sampling consists of chicken, beef and lard. Both of chicken and beef were obtain from local market whereas lard got from slaughter house. Each of tissues samples were cut into small pieces and directly melted at $75^{\circ} \mathrm{C}$ through of physical chemistry test were determined consist of density, refractive index, melting point, iodine value and saponification value. Further analysis had been carried out by FTIR (Fourier Transform Infra red) and GCMS (Gas Chromatography Mass Spectromtery) to identify spectral bands and proportional of fatty acid composition of each samples. Based on this result, the physical chemistry characteristic of each sample had no significantly different except on melting point, iodine value and saponification value. Therefore, FTIR spectral data give a specific difference in frequency region 3010, 1110-1095 and the bands associated fingerprint region $975-965 \mathrm{~cm}^{-1}$ which represented of fatty acid contain. Due to this result, the GCMS data give a clearly information about the difference of proportions of SFA (saturated fatty acid), MUFA (monounsaturated fatty acid) and PUFA (polyunsaturated fatty acid) on each samples.
\end{abstract}

Key words : animal fat, phisical chemistry characteristic, FTIR, GCMS, SFA, MUFA, PUFA

\section{PENDUHULUAN}

Masalah kehalalan pangan merupakan isu yang sering menjadi polemik di masyarakat. Salah Satu faktor penyebab timbulnya isu ini antara lain adalah kurangnya perhatian dan pengawasan dari pemerintah terhadap para produsen yang bergerak dalam bidang pengolahan dan pengadaan bahan pangan (Apriyantono, 2000). Sejauh ini, Pemerintah Indonesia melalui SK bersama (LPPOM MUI, Depag dan BPOM Depkes) 
telah mencanangkan Sistem Jaminan Halal yang diwujudkan dalam bentuk Sertifikasi Halal bagi setiap produsen produk pangan. Namun demikian implementasi sistem jaminan halal ini dalam kenyataannya masih menemukan berbagai kendala, salah satunya adalah ketiadaan metode yang benar-benar efektif untuk menganalisa substansi produk pangan yang benar-benar bisa menjamin kehalalan dari produk pangan tersebut (Apriyantono, 2001).

Salah satu metode yang dapat dikembangkan dalam menganalisa kehalalan produk pangan yang mengandung lemak hewani khususnya lemak babi adalah dengan melihat komposisi asam lemak yang terkandung di dalamnya. Hal ini dapat dilakukan dengan mengubah asam lemak tersebut menjadi derivat esternya yang selanjutnya dapat dianalisa dengan alat GCMS (Gas Chromatography Mass Spectrofotometry) (Janusz C., 2003). Analisa lain yang dapat dilakukan adalah dengan melihat pola spektrumnya dengan menggunakan alat Fourier Transform InfraRed (FTIR) Spectrofotometry.

Berdasarkan hasil penelitian yang telah dilakukan oleh Irwandi Jaswir (2005), metode FTIR sangat berpotensi untuk digunakan sebagai alat pendeteksi lemak babi secara cepat dengan hasil yang konsisten. Hal ini dikarenakan Metode FTIR dapat memberikan hasil analisa asam lemak dari babi yang bercampur dengan lemak-lemak binatang lainnya secara konsisten, bahkan dengan kandungan yang sangat rendah (Irwandi Jaswir, 2005).

Eksplorasi metode analisa lemak hewani khususnya lemak babi dengan alat FTIR memungkinkan untuk dikembangkan terutama karena efisiensi dan kesedehanaan proses yang dilakukan. Metode analisa ini juga tidak memerlukan preparasi sampel yang rumit dimana baik sampel padatan maupun cairan bisa langsung dianalisa untuk menghasilkan spectrum. (Irwandi J., 2005).

Namun demikian metode FTIR juga memiliki keterbatasan terutama karena metode ini tidak dapat mengidentifikasi jenis dan kandungan masing-masing komponen asam lemak dari suatu sampel secara pasti. Untuk itu, hasil analisa FTIR juga perlu ditunjang oleh hasil analisa GCMS terutama untuk menentukan komposisi asam lemak manakah yang paling dominan dari suatu sampel.

Sebagai studi pendahuluan, telah dilakukan analisa profil asam lemak dari jaringan lemak hewani yang meliputi lemak ayam, sapi dan babi dengan melihat pola spektumnya melalui analisa FTIR yang kemudian dilanjutkan dengan analisa GCMS terutama untuk menentukan perbedaan komposisi asam lemak pada masing-masing sampel. Untuk menunjang hasil analisa juga dilakukan penentuan sifat fisikokimia pada masing-masing sampel.

\section{METODE PENELITIAN}

\section{Bahan dan Alat}

Bahan yang digunakan meliputi sampel jaringan lemak hewani yang terdiri dari lemak ayam dan lemak sapi yang diperoleh dari pasar lokal, dan lemak babi yang diambil dari RPH Cakung Jakarta Timur. Larutan BF3 (Boron trifluorida) dalam metanol digunakan untuk esterifikasi asam lemak. larutan, n-heksan (p.a) sebagai pelarut untuk ekstraksi lemak/minyak (Merck). $\mathrm{Na}_{2} \mathrm{SO}_{4}$ anhidrus untuk memurnikan lemak.

Peralatan yang digunakan terdiri dari Gas Chromatoghrapy Mass Spectrofotometry (GCMS) QP-2010 Shimadzu Japan dengan

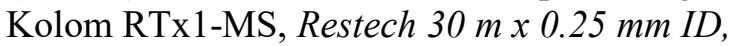
$0.25 \mu \mathrm{m}, \quad$ Polymethyl xiloxane. Sepektrofotometer Fourier Transform Infra Red (FTIR) Spectrum One Perkin Elmer, USA, Refractometer Abbe untuk penentuan indeks bias.

\section{Ekstraksi Lemak Padat (Metode Oven)}

2 gram sampel jaringan lemak dicuci, diiris kecil-kecil dan dimasukkan ke dalam becker glass. Selanjutnya sampel dimasukkan ke dalam dry oven yang sudah diatur suhunya $\left(75^{\circ} \mathrm{C}\right)$, dibiarkan selama 6 jam hingga jaringan lemaknya mencair. Lemak padat yang sudah mencair dipisahkan dan dimasukkan ke dalam corong pisah untuk selanjutnya dimurnikan dengan penambahan pereaksi nheksan. Lemak yang sudah dimurnikan disaring dalam kertas saring yang sudah ditambahkan natrium sulfat $\left(\mathrm{Na}_{2} \mathrm{SO}_{4}\right)$ untuk mengikat air yang masih ada pada lapisan lemak. Hasil ekstraksi ditimbang dan ditentukan persen randemennya. 


\section{Pengujian Sifat Fisikokimia}

Pengujian sifat fisikokimia dilakukan terhadap masing-masing sampel lemak hewani yang meliputi :bobot jenis, indeks bias, titik leleh, bilangan iodin dan bilangan penyabunan (AOAC, 2000). Hasil analisa dibandingkan satu sama lain dan diuji lebih lanjut tingkat perbedaaannya dengan uji keragaman (T test).

\section{Analisa pola spektrum lemak hewani dengan FTIR}

Sampel lemak yang telah disaring dan dimurnikan diteteskan pada salah satu permukaan sel KBr. Diantara kedua sel $\mathrm{KBr}$ diberi pembatas berupa politetrafluoroetilen (PTFE) untuk menghasilkan ketebalan lapisan lemak $0.1 \mathrm{~mm}$. Sel bagian lainnya ditangkupkan hingga terbentuk lapisan tipis lemak. Scaning dilakukan dengan kisaran panjang gelombang $4000 \mathrm{~cm}^{-1}$ sampai $650 \mathrm{~cm}^{-}$ 1 dengan resolusi $4 \mathrm{~cm}^{-1}$. Hasil scaning direkam dan dianalisa lebih lanjut.

\section{Esterifikasi asam lemak}

2 gram sampel lemak yang telah diekstrak dimasukkan ke dalam tabung reaksi dan direaksikan dengan $\mathrm{BF}_{3}$ dalam metanol. Dikocok dan dipanaskan selama \pm 15 menit. Didiamkan sampai terbentuk 2 lapisan. Lapisan atas dipisahkan dengan sentrifugasi dan dipurifikasi lebih lanjut dengan menambahkan $\mathrm{Na}_{2} \mathrm{SO}_{4}$ untuk menghilangkan kadar airnya. Hasil esterifikasi selanjutnya dimasukkan ke dalam vial untuk dianalisa dengan alat GCMS.

\section{Analisa komposisi asam lemak dengan GCMS}

$1 \mu \mathrm{L}$ sampel lemak yang telah diesterifikasi diinjeksikan ke dalam kolom GC dengan menggunakan metode autosampler. Pemisahan dilakukan dalam kolom RTx 1-MS Restech, $30 \mathrm{~m} \times 0.25 \mathrm{~mm} \mathrm{ID}, 0.25 \mu \mathrm{m}$, dengan fase diam Polymethyl xiloxan, suhu injektor $280^{\circ} \mathrm{C}$, suhu kolom $70^{\circ} \mathrm{C}$ dan dinaikan sampai $300^{\circ} \mathrm{C}$ dengan kenaikan $10^{\circ} \mathrm{C} /$ menit, laju alir $1,15 \mathrm{~mL} / \mathrm{menit}$. Detektor MS yang digunakan adalah Electron Multifier Detector (EMD) 70 $\mathrm{MeV}$. Hasil analisa berupa spektrum massa dibandingkan dengan library WILLEY147 \& NIST47 yang terdapat pada software GCMS postrun anlysis.

\section{HASIL DAN PEMBAHASAN}

\section{Hasil ekstraksi lemak}

Dari ketiga sampel jaringan lemak yang diekstraksi (ayam, sapi dan babi) dengan bobot cuplikan yang relatif sama diperoleh kadar lemak yang berbeda seperti terlihat pada tabel 1.

Tabel 1. Kadar lemak masing-masing sampel

\begin{tabular}{|l|c|l|}
\hline \multicolumn{1}{|c|}{ Sampel } & \multicolumn{1}{c|}{$\begin{array}{c}\text { Bobot } \\
\text { sampel }\end{array}$} & \multicolumn{1}{c|}{$\begin{array}{c}\text { Kadar lemak } \\
(\% \mathrm{w} / \mathrm{w})\end{array}$} \\
\hline Daging ayam & $498,20 \mathrm{~g}$ & 10.9 \\
\hline Daging sapi & $501.12 \mathrm{~g}$ & 4.5 \\
\hline Daging babi & $502.75 \mathrm{~g}$ & 8.2 \\
\hline
\end{tabular}

Kandungan lemak pada ketiga sampel yang diekstraksi menunjukkan sampel daging ayam relatif lebih tinggi dibandingkan dengan lemak sapi dan lemak babi. Perbedaan kadar lemak ini kemungkinan disebabkan karena secara alamiah kandungan lemak pada setiap spesies relatif berbeda. Disamping itu, perbedaan jenis cuplikan (bagian/jaringan otot daging) yang digunakan juga tidak sama.

\section{Perbedaan sifat fisikokimia}

Hasil pengujian sifat fisikokimia pada masing-masing sampel tidak meunujukan perbedaan yang cukup signifikan kecuali untuk parameter titik leleh, bilangan iodin dan bilangan penyabunannya, sebagaimana terlihat pada tabel 2 .

Tabel 2. Sifat fisikokimia hasil pengamatan

\begin{tabular}{|c|c|c|c|}
\hline Parameter & $\begin{array}{c}\text { Lemak } \\
\text { sapi }\end{array}$ & $\begin{array}{c}\text { Lemak } \\
\text { babi }\end{array}$ & $\begin{array}{c}\text { Lemak } \\
\text { ayam }\end{array}$ \\
\hline $\begin{array}{c}\text { Bobot jenis } \\
(\mathrm{g} / \mathrm{mL})\end{array}$ & 0.8999 & 0.8940 & 0.8769 \\
\hline Indeks bias & 1.460 & 1.462 & 1.461 \\
\hline Titik leleh & $\mathbf{4 3 . 5}$ & $\mathbf{3 6 . 0}$ & $\mathbf{3 4 . 5}$ \\
\hline Bilangan Iod & $\mathbf{4 5 . 7 5}$ & $\mathbf{7 2 . 6 9}$ & $\mathbf{6 2 . 8 1}$ \\
\hline $\begin{array}{c}\text { Bilangan } \\
\text { penyabunan }\end{array}$ & $\mathbf{2 3 7 . 5 7}$ & $\mathbf{2 5 7 . 7 0}$ & $\mathbf{2 5 9 . 7 7}$ \\
\hline
\end{tabular}

Berdasarkan tabel 2 di atas, perbedaan titik leleh disebabkan oleh komposisi asam lemak pada masing-masing sampel. Banyaknya asam lemak jenuh dan asam lemak berantai panjang akan memberikan kontribusi yang nyata bagi peningkatan titik leleh lemak secara keseluruhan (Nielsen S., 2003). Hal yang sama juga berlaku pada perbedaan nilai bilangan iod dan bilangan penyabunan, dimana komposisi asam lemak tidak jenuh pada setiap sampel 
akan berkontribusi pada peningkatan harga bilangan iodnya, sedangkan perbedaan komposisi asam lemak (rantai pendek, sedang dan panjang) akan sangat berpengaruh terhadap harga bilangan penyabunannya. Dengan demikian berdasarkan hasil pengujian sifat fisikokimia untuk setiap sampel, terlihat bahwa terdapat perbedaan komposisi asam lemak dan perbandingan asam lemak jenuh/tidak jenuh pada setiap sampel.

\section{Profil lemak hewani hasil analisa FTIR}

Analisa spektroskopi FTIR didasarkan pada karakteristik gugus fungsi yang terdapat pada ketiga sampel lemak. Data spektra FTIR masing-masing sampel diperoleh dari hasil
FTIR Spectrum One Perkin Elmer pada daerah IR dengan frekuensi $4000-600 \mathrm{~cm}^{-1}$ dan resolusi $4 \mathrm{~cm}^{-1}$ (Gambar 1 dan 2).

Berdasarkan data tersebut, terlihat bahwa spektra FTIR dari sampel lemak secara umum menunjukan perbedaan yang menonjol pada serapan $\mathrm{C}-\mathrm{H}$ streching di daerah bilangan gelombang 3050-2800, serapan gugus karbonil $(\mathrm{O}=\mathrm{C}-\mathrm{OR})$ dari ester asam lemak pada daerah 1746-1744, dan pola serapan daerah sidik jari, 1000-900 $\mathrm{cm}^{-1}$ (Gambar 1 dan Gambar 2). Perbedaan yang cukup signifikan terlihat pada penyerapan spektra di daerah 3010-3000, 1120-1095 dan 968-966 $\mathrm{cm}^{-1}$. Untuk sampel lemak babi, pola serapan yang muncul pada daerah $3010 \mathrm{~cm}^{-1}$ menunjukkan puncak yang relatif tinggi jika dibandingkan dengan kedua

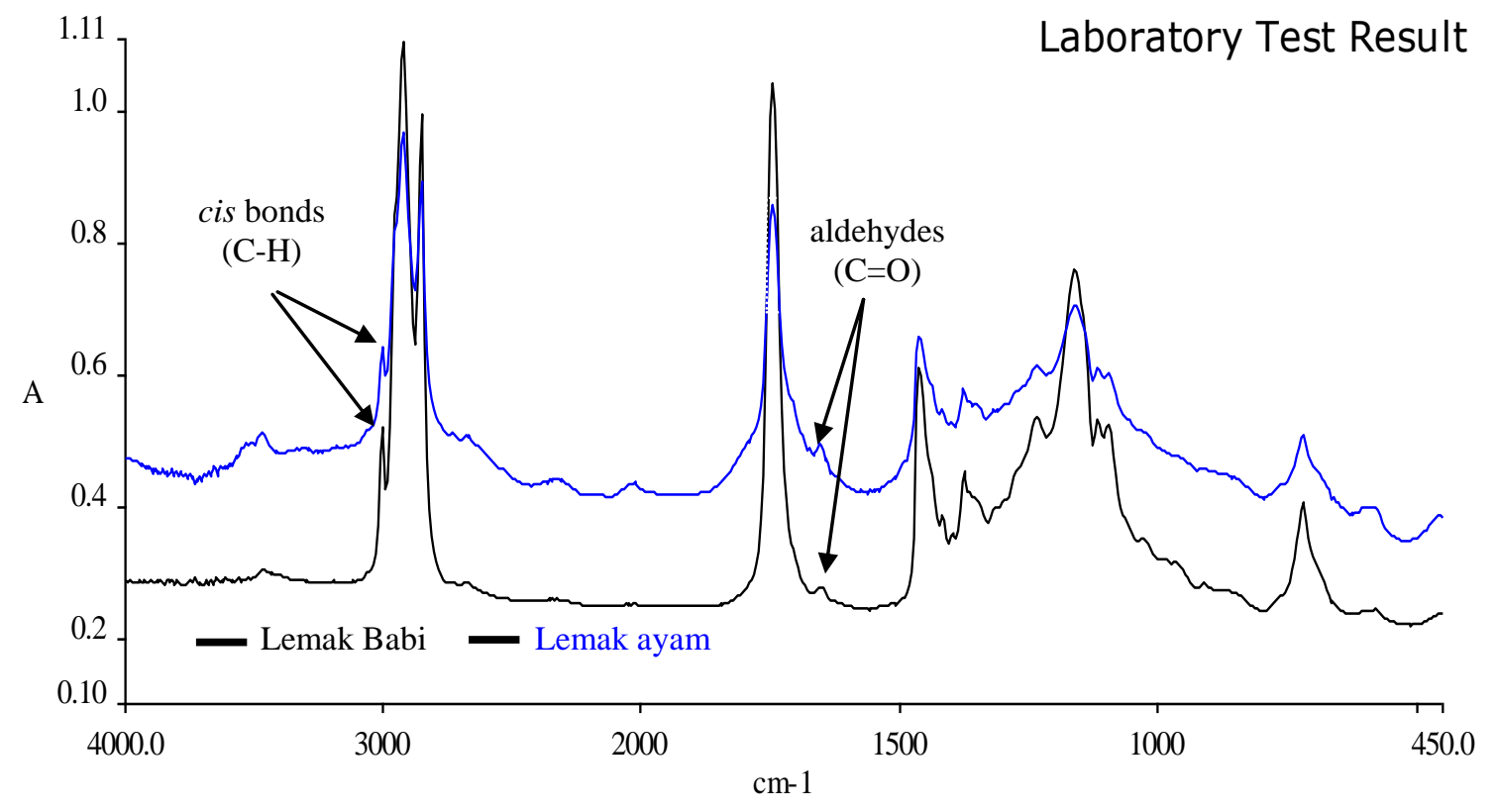

scaning sampel lemak murni dengan alat Tingginya puncak serapan untuk lemak babi pada daerah ini merepresentasikan streching vibration dari ikatan rangkap $\mathrm{C}=\mathrm{C}$ cis. Hal ini sejalan dengan hasil penelitian Irwandi, 2003 dimana untuk sampel lemak babi, kandungan asam lemak tidak jenuh ganda (polyunsaturated fatty acids) atau PUFA seperti asam linoleat dan asam linolenat jauh lebih besar daripada asam lemak jenuh tunggal (mono unsaturated fatty acids) atau MUFA. Selanjutnya pada daerah frekuensi 1120-1095 $\mathrm{cm}^{-1}$, sampel lemak babi menunjukkan adanya overlaping dari dua peak dengan absorbasni maksimum pada bilangan gelombang 1118 dan $1098 \mathrm{~cm}^{-1}$. Berbeda sampel lemak lainnya (ayam dan sapi).

dengan pola spektrum yang dihasilkan untuk sampel lemak sapi dan lemak ayam, dimana untuk kedua sampel tidak menunjukan adanya overlaping kecuali untuk lemak ayam dengan pola yang hampir mirip dengan lemak babi. Hal ini mengindikasikan kemungkinan adanya perbedaan profil asam lemak pada ketiga sampel tersebut. Hal ini diperkuat oleh penelitian Irwandi, 2003 yang menyatakan bahwa operlaping pada dua daerah bilangan gelombang tersebut menunjukkan adanya perbedaan kandungan asam lemak jenuh dan asam lemak tidak jenuh dari masing-masing sampel. 
Titik perbedaan ketiga dari pola spektrum masing-masing sampel muncul pada daerah bilangan gelombang $966-967 \mathrm{~cm}^{-1}$ yang menunjukan keberadaan asam lemak tidak jenuh trans. Pada sampel lemak babi, terlihat tidak ada puncak yang muncul pada daerah tersebut atau dengan kata lain serapan pada daerah tersebut sangat lemah. Begitu pula kandungan asam lemak trans jauh lebih besar dibandingkan dengan kedua sample lainnya (ayam dan babi). Hal ini sesuai dengan standar yang telah ditetapkan oleh AOCS (Amercan Oils Chemistry Standard) dimana rentang frekuensi IR pada daerah 975-965 $\mathrm{cm}^{-1}$ merupakan dasar dari metode kuantisasi asam lemak trans dalam sampel lemak/minyak (J.M.

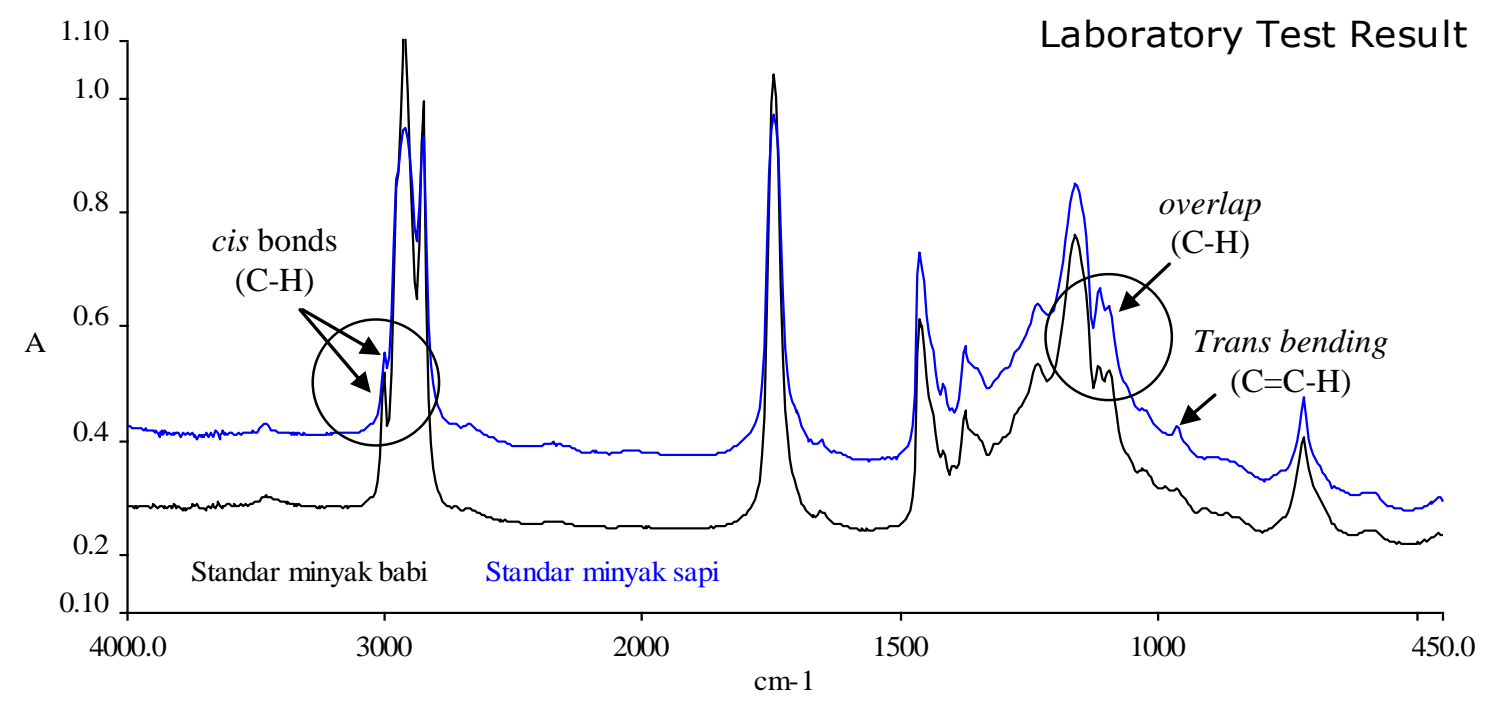

Gambar 2. Perbandingan spektrum FTIR untuk lemak babi dan lemak ayam

untuk pola spektrum lemak ayam. Namun demikian berbeda untuk lemak sapi, dimana Komposisi asam lemak hasil analisa GCMS

Analisa GCMS dilakukan untuk mengetahui komposisi masing-masing asam lemak dari ketiga sampel (ayam, sapi dan babi) dilihat dari presentasi asam lemak jenuh dan tidak jenuhnya. Analisa dilakukan terhadap ketiga sampel lemak hewani yang telah diesterifikasi sebelumnya dan dikaraktersiasi de Man, 1999).

lebih lanjut dengan menggunakan instrumen GCMS QP2010 dengan kolom RTx 1MS Restech $30 \mathrm{~m} \times 0.25 \mathrm{~mm} \mathrm{ID}, 0.25 \mu \mathrm{m}$, dengan fase diam Polymethyl xiloxane dan suhu injektor 210, suhu detektor 230 serta laju alir 1 $\mathrm{mL} / \mathrm{menit}$.

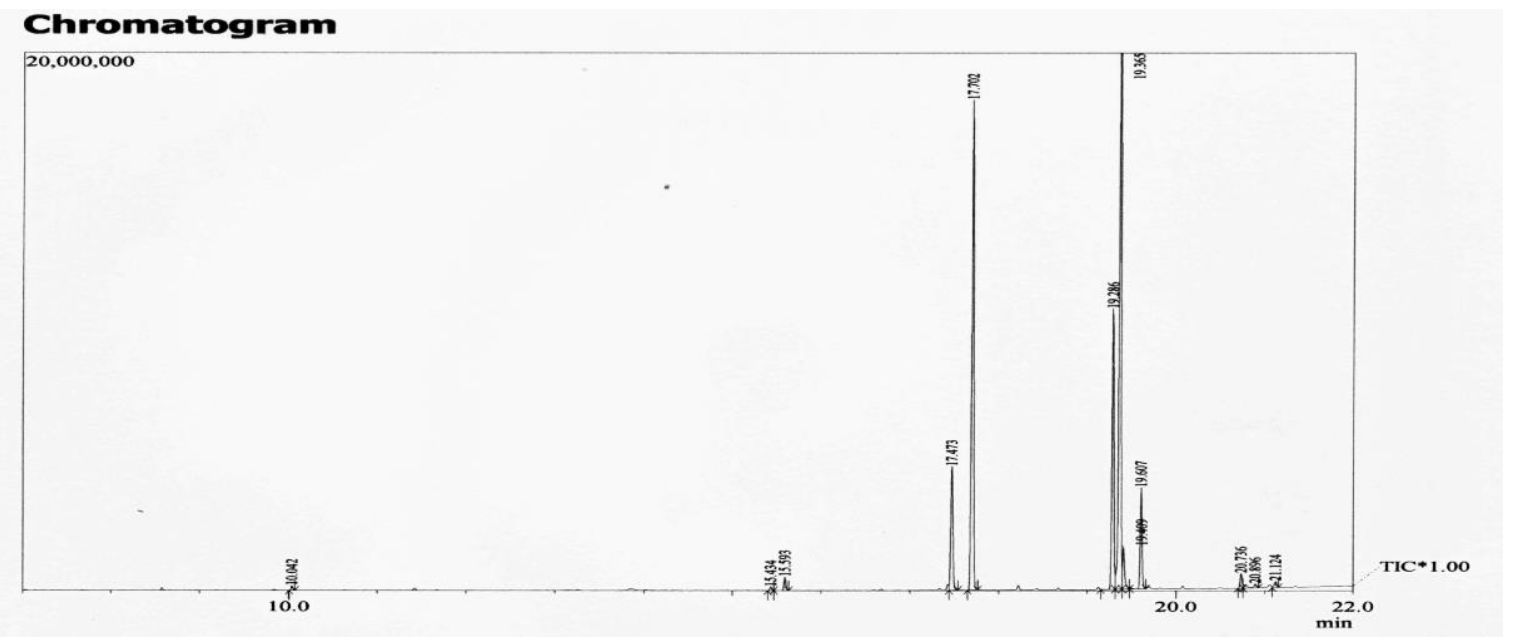

Gambar 3. . Total ion Chromatogram lemak ayam hasil pemisahan GCMS QP 2010, Kolom RTx1-MS 


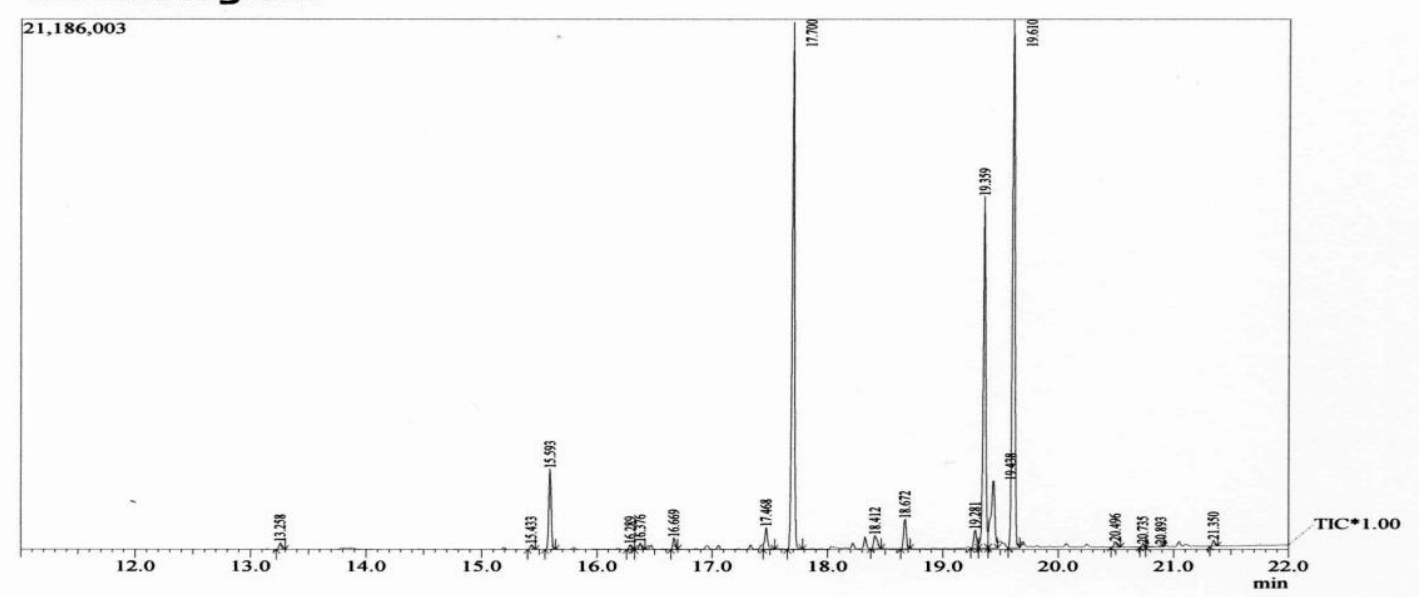

Gambar 4. Total ion Chromatogram lemak sapi hasil pemisahan GCMS QP 2010, Kolom RTx1-MS

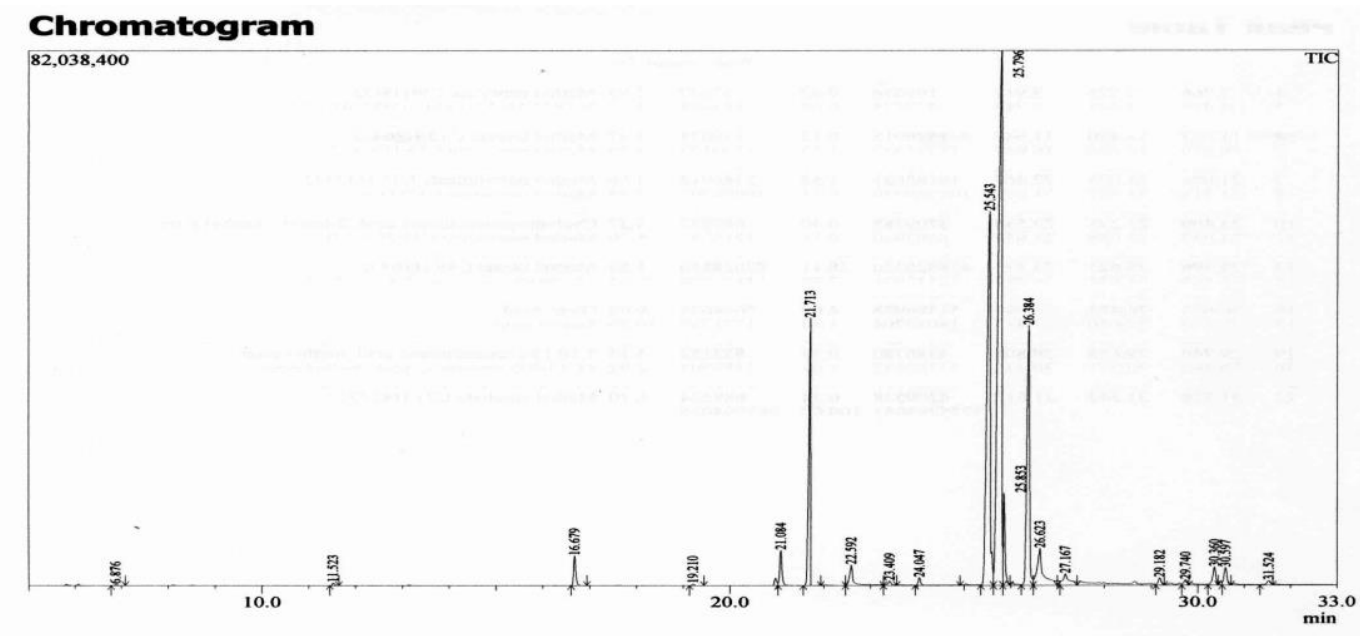

Gambar 5. Total ion Chromatogram lemak babi hasil pemisahan GCMS QP 2010, Kolom RTx1-MS

Berdasarkan kromatogram ketiga sampel lemak hewani hasil pemisahan GCMS, diperoleh kandungan asam lemak jenuh dan tidak jenuh dengan komposisi yang relatif berbeda untuk ketiga sampel sebagaimana tercantum dalam tabel 3.

Tabel 3. Komposisi asam lemak pada masingmasing sampel

\begin{tabular}{|l|c|c|c|}
\hline \multirow{2}{*}{ Asam Lemak } & \multicolumn{3}{|c|}{ Persentase asam lemak (\%) } \\
\cline { 2 - 4 } & $\begin{array}{c}\text { Lemak } \\
\text { Ayam }\end{array}$ & $\begin{array}{c}\text { Lemak } \\
\text { Sapi }\end{array}$ & $\begin{array}{c}\text { Lemak } \\
\text { Babi }\end{array}$ \\
\hline Asam Kaprilat C8:0 & td & td & 0.01 \\
\hline Asam Kaprat C10:0 & td & td & 0.04 \\
\hline Asam Laurat C12:0 & td & 0.34 & 0.1 \\
\hline Asam Miristat C14:0 & 0.74 & 4.36 & 1.07 \\
\hline Asam Palmitoleat C16:1 & 7.01 & 1.40 & 1.78 \\
\hline Asam Palmitat C16:0 & 27.24 & 29.40 & 7.01 \\
\hline Asam Margarat C17:0 & td & 1.74 & 0.5 \\
\hline Asam Linoleat C18:2 & 16.36 & 1.17 & 24.94 \\
\hline Asam Oleat C18:1 & 38.35 & 20.53 & 40.74 \\
\hline Asam Stearat C18:0 & 5.56 & 31.26 & 13.95 \\
\hline Asam Arakidonat C20:4 & 0.87 & td & 0.43 \\
\hline Asam Eikosenat C20:1 & 0.41 & td & td \\
\hline Asam Arakat C20:0 & td & 0.33 & 0.3 \\
\hline
\end{tabular}

Dari ketiga sampel yang dianalisa terlihat bahwa kandungan asam lemak rantai pendek C8 - C12 untuk semua sampel hampir tidak terdeteksi kecuali pada sampel lemak babi dengan presentasi yang relatif rendah. Berbeda dengan asam lemak jenuh rantai panjang (C16:0, C18:0 dan C20:0), pada lemak sapi kandungannya jauh lebih besar dibandingkan dengan lemak babi dan lemak ayam, sedangkan untuk asam lemak tidak jenuh tunggal (MUFA) dan asam lemak tidak jenuh ganda (PUFA) pada masing-masing sampel cukup bervariasi. Yang paling menonjol adalah kandungan asam linoleat (C18:2) untuk sampel lemak sapi jauh lebih rendah dibandingkan lemak ayam dan lemak babi, bahkan untuk asam arakidonat (C20:4) pada sampel lemak sapi tidak terdeteksi. Untuk asam lemak jenuh C17:0 dan C20:0 pada lemak ayam tidak terdeteksi sedangkan pada sampel lemak sapi dan babi keduanya 
mengandung asam lemak tersebut walaupun dengan presentasi yang relatif rendah.

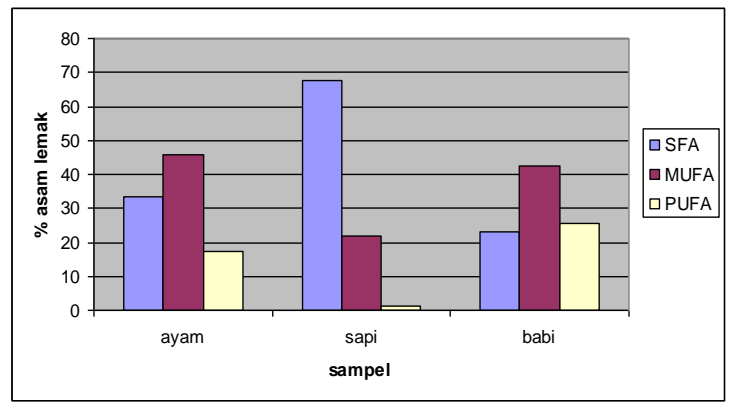

Perbedaan komposisi asam lemak jenuh (SFA), asam lemak jenuh tunggal (MUFA) dan asam lemak jenuh ganda (PUFA) dari ketiga sampel menunjukkan bahwa kandungan asam lemak jenuh untuk lemak sapi jauh lebih besar (68\%) dibandingkan lemak ayam (33\%) dan lemak babi (21\%), sedangkan komposisi asam lemak tidak jenuh tunggal (MUFA) untuk lemak ayam dan lemak babi relatif lebih besar dibandingkan dengan lemak sapi. Perbedaan yang cukup signifikan teletak pada kandungan asam lemak jenuh ganda (PUFA) dimana untuk lemak babi (25\%) jauh lebih besar daripada lemak ayam (18\%) dan lemak sapi $(1.2 \%)$.

Walaupun demikian, untuk mengidentifikasi perbedaan dan spesifitas lemak hewani secara lebih kuantitatif perlu dilakukan pengujian sampel melalui beberapa perlakuan khusus, misalnya dengan variasi waktu dan suhu pemanasan serta proses pencampuran lemak babi dengan lemak hewani lainnya. Hal ini perlu dilakukan terutama dalam upaya pengembangan metode analisa kehalalan pangan, dimana sebagian besar produk pangan yang diragukan kehalalannya umumnya merupakan produk pangan olahan yang telah mengalami proses pemanasan (heating procces) atau pencampuran (adulteration).

\section{KESIMPULAN}

1. Profil asam lemak hasil analisa FTIR menunjukkan adanya perbedaan puncak serapan pada daerah bilangan gelombang $3010 \mathrm{~cm}^{-1}$ serta overlaping puncak serapan pada daerah frekuensi $1120-1095 \mathrm{~cm}^{-1}$ dan adanya serapan pada daerah $975-965 \mathrm{~cm}^{-1}$ yang merepresentasikan perbedaan komposisi dan jenis asam lemak pada masing-masing seampel.

2. Terdapat perbedaan komposisi asam lemak yang cukup signifikan diantara ketiga sampel lemak hewani berdasarkan hasil analisa GCMS dimana kandungan asam lemak jenuh (SFA) pada lemak sapi jauh lebih besar (68\%) dibandingkan dengan lemak ayam (33\%) dan lemak babi (21\%), sedangkan kandungan asam lemak jenuh ganda (PUFA) pada lemak babi relatif lebih besar $(25 \%)$ daripada lemak ayam $(18 \%)$ dan lemak sapi (1.2\%).

\section{DAFTAR PUSTAKA}

A.O.A.C 17th edn, 2000, Official Method of Oils and Fats.

Anggraeni R. S., 2003, Mensikapi Keputusan Menteri Agama Republik Indonesia Nomor 518 Tahun 2001 Tentang Pedoman Dan Tatacara Pemeriksaan Dan Penetapan Pangan Halal, Yayasan Halal Thoyyiban, Bogor.

Apriyantono A., 2001, Sistem Sertifikasi Halal di Indonesia, Seminar Pangan, Teknologi Pangan dan Gizi, Fakultas teknologi Pertanian, IPB.

David F., Sandra P., 2005, Column Selection for Analysis of Fatty Acid Methyl Esters, Research Institute For Chromatography, Agilent Technology, USA.

Irwandi J., Saeed M.E., Torla, H., and Zaki, M., Determination of Lard in Mixture of body fats of Mutton and Cow by Fourier Transform Infrared Spectroscopy, J. Oleo Sci., Vol 52, No. 12, 633-638, 2003.

J.M. de Man, 1999, Fungtionality Requirements of Fats and Oils for Food Applications, MOSTA Tech-In, Recent Advance in The Science of Oils and Fats, Canada.

Janusz Czarniecki, 2003, GC/MS Analysis for Unsaturated Fat Content in Animal Feed, Nafag Company, Gossau, Switzerland.

Paquot C., 1999, Standard Method for The Analysis of Oils, Fats and Derivated, $6^{\text {th }}$ edition, Section II : Oils and Fats, Groupe The Laboratoires du CNRS Thiaise, France.

Richard Crowley, 2006, The Chemistry and Analysis of Trans Fatty Acids, Food Product Design, Food Science Newsletter, New York, USA. 
JURNAL VALENSI, Vol. 1 No. 3 November 2008, 102-109 